\title{
ANALYSIS OF JAVANESE LANGUAGE VOCABULARY SKILL FOR ELEMENTARY SCHOOL STUDENTS IN KEBUMEN DISTRICT
}

\section{Liftahul Sekar Aji, Sugiharti, Moh Salimi}

Universitas Sebelas Maret

liftasekar@gmail.com

\section{Article History}

accepted 30/09/2018

approved 12/10/2018

published $30 / 10 / 2018$

\section{Keywords}

mastery, vocabulary,

javanese language

\begin{abstract}
Students are more proficient in foreign languages and Indonesian, this can be seen from everyday conversations that rarely use Javanese. This study aims to determine the vocabulary mastery of Javanese language in elementary school students. This research method uses qualitative descriptive research method. The subjects of this study were the fifth grade students of Kutosari 7 State Elementary School and Pekunden Elementary School. Data collection was carried out using questionnaire instruments and tests in the form of student worksheets. The results of this study indicate that elementary school students lack mastery of Javanese language.
\end{abstract}

Social, Humanities, and Education Studies (SHEs): Conference Series

p-ISSN 2620-9284 https://jurnal.uns.ac.id/shes

e-ISSN 2620-9292 


\section{PENDAHULUAN}

Indonesia merupakan negara yang memiliki beragam suku dan budaya.Keberagaman suku dan budaya tersebut juga berdampak pada keberagaman bahasa daerah. Menurut Tondo (2009: 278) di Indonesia terdapat 742 bahasa, 737 bahasa di antaranya merupakan bahasa yang masih hidup atau masih digunakan oleh penuturnya. Pada hakikatnya, bahasa berperan sebagai sarana komunikasi.Kemampuan penguasaan bahasa dapat meningkatkan kemampuan komunikatif, yaitu kemampuan untuk bertindak dan berhubungan sosial dengan bahasa sebagai alat utamanya.

Salah satu bahasa yang ada di Indonesia adalah bahasa Jawa. Di zaman yang sudah semakin maju dengan era digital ini, Menurut Wulandari (2012:16) bahasa jawa memiliki dua tingkat tutur yang dipakai yaitu tingkat tutur halus dan tingkat tutur kasar. Untuk tingkat tutur halus dibedakan menjadi dua yaitu krama lugu dan karma alus sedangkan untuk tingkat tutur kasar yaitu ngoko lugu dan ngoko alus. Menurut Waluyo (2010: 21) krama lugu yaitu ragam bahasa Jawa yang keseluruhannya dibentuk dari koasakata karma.Dalam bahasa Jawa Krama lugu terdapat beberapa ciri, yaitu semua kosakata yang digunakan merupakan kosakata karma, semua awalan dan akhiran dikramakan.Sedangkan karma alus menurut Waluyo (2010: 21) adalah ragam bahasa Jawa yang keseluruhannya dibentuk dari kosakata krama inggil dengan ciri yaitu kosakata yang digunakan adalah kosakata krama dan krama inggil, awalan dan akhiran dikramakan.

Ditinjau dari jumlah penuturnya, bahasa Jawa memiliki jumlah penutur terbanyak di Indonesia dibandingkan bahasa daerah lain seperti bahasa Sunda dan bahasa Madura. Menurut Anwar (2013: 27) jumlah orang yang menggunakan bahasa Jawa diperkirakan mencapai 75 juta jiwa, dan pengguna bahasa Jawa menempati urutan ke 11 dan 15 besar pengguna bahasa di dunia. Bahasa jawa terkenal cukup rumit, karena bahasa jawa memiliki sistem tingkatan atau yang disebut dengan unggah-ungguh basa.Unggah-ungguh ini digunakan sebagai derajat hormat penutur kepada mitra tutur lawan bicaranya. Karena kerumitan bahasa Jawa maka banyak orang yang tidak mengerti akan kosakata bahasa Jawa.

Seiring dengan perkembangan zaman, kini jumlah penutur bahasa jawa semakin berkurang. Menurut Tondo (2009) berkurangnya jumlah penutur bahasa Jawa karena terdesak oleh pengaruh bahasa-bahasa daerah lain yang lebih dominan dan pengaruh dari bahasa Indonesia sebagai bahasa nasional terutama dalam berbagai ranah resmi. Selain itu juga karena pengaruh dari perkembangan teknologi yang semakin berkembang dengan pesat, yang mengakibatkan globalisasi, sehingga memudahkan bahasa maupun budaya asing untuk masuk ke Indonesia.Bahasa jawa kini semakin asing terutama di kalangan anak-anak dan remaja.Dalam kehidupan sehari-hari mereka hanya mampu menggunakan bahasa jawa ngoko baik dengan teman sejawat maupun orang yang lebih dihormati, hal ini menunjukkan kesulitan dalam menerapkan unggah-ungguh. Bahkan, tidak sedikit di antara mereka yang menggunakan bahasa Indonesia maupun bahasa asing dalam bercakap sehari-hari. Menurut Khasanah (2012: 2) pergeseran penggunaan bahasa Jawa Krama disebabkan oleh beberapa hal, yaitu adanya perkembangan media informasi, pembelajaran bahasa daerah yang semakin tergeser, dan lingkungan yang semakin tidak kondusif dalam mempertahankan penggunaan bahasa Jawa.

Melestarikan bahasa Jawa juga telah diupayakan melalui pembelajaran di lingkungan sekolah formal. Bahasa jawa merupakan muatan lokal yang memiliki alokasi waktu 2 jam pelajaran selama satu minggu. Bahasa jawa juga telah diajarkan mulai kelas 1 Sekolah Dasar.Pembelajaran bahasa jawa meliputi empat aspek ketrampilan berbahasa, yaitu menulis, membaca, menyimak dan berbicara.Namun, pada kenyataannya masih terdapat kendala dalam pelestarian bahasa Jawa di lingkungan sekolah, menurut Utari (tanpa tahun) siswa merasakan kesulitan dalam 
pembelajaran bahasa Jawa.Banyak siswa yang tidak terbiasa menggunakan bahasa Jawa dalam berkomunikasi di kehidupan sehari-hari.Banyak peserta didik yang merasakan kesulitan dalam mempelajari bahasa jawa, salah satu penyebabnya yaitu karena rendahnya tingkat penguasaan kosakata bahasa Jawa Krama. Menurut Pratiwi, Hafidah dan Syamsuddin (2015: 2) kemampuan kosakata merupakan salah satu syarat utama menentukan keberhasilan seseorang untuk terampil berbahasa, semakin banyak kosakata yang dimiliki seseorrang semakin mudah pula ia menyampaikan dan menerima informasi, baik secara lisan maupun tulisan.

Penilitian ini memilih SD Negeri Pekuden yang merupakan salah satu sekolah yang terletak di kecamatan Kutowinangun, kabupaten Kebumen sedangkan SD Negeri 7 Kutosari terletak di kecamatan Kebumen, kabupaten Kebumen, sehingga ditinjau dari keadaan lingkungan, SD Negeri Pekunden terletak di lingkungan pedesaan, sedangkan SD Negeri 7 Kutosari terletak di lingkungan perkotaan.

Dalam penelitian kali ini menggunakan empat instrument penilaian yaitu aspek pengetahuan yang meliputi kegiatan mengubah kalimat yang kurang tepat, yang kemudian disesuaikan dengan unggah-ungguh basa serta mengubah bahasa jawa ngoko menjadi bahasa jawa Krama, bahasa Jawa Krama inggil dan bahasa Indonesia. Untuk aspek ketrampilan menulis, yaitu dengan membuat surat sesuai dengan unggah ungguh basa dengan minimal 2 paragraf. Sedangkan untuk aspek ketrampilan membaca yaitu dengan membaca sebuah berita yang menggunakan bahasa Jawa Krama, kemudian diberikan beberapa pertanyaan terkait berita tersebut, dan untuk aspek berbicara yaitu dengan memberikan saran atau tanggapan secara lisan terkait dengan bacaan. Untuk penilaian masing-masing aspek yaitu 25. Penyusunan ke empat aspek tersebut didasarkan pada SK Gubernur Jawa Tengah Nomor 423.5/5/2010 tentang Kurikulum Mata Pelajaran Muatan Lokal (Bahasa Jawa) Untuk Jenjang Pendidikan SD/SDLB/MI dan SMP/SMPLB/Mts Negeri dan Swasta Provinsi Jawa Tengah.

Penelitian ini bertujuan untuk mengidentifikasi tingkat penguasaan kosakata bahasa Jawa Krama di SD Negeri Pekunden dan SD Negeri 7 Kutosari pada siswa kelas 5.

\section{METODE}

Penelitian ini menggunakan metode deskriptif kualitatif. Menurut Prabowo dan Heriyanto (2013: 5) deskriptif kualitatif adalah metode pengolahan data dengan cara menganalisa faktor-faktor yang berkaitan dengan objek penelitian dengan penyajian data secara lebih mendalam terhadap objek penelitian. Subjek dari penelitian ini adalah siswa kelas 5 di SD Negeri Pekunden dan SD Negeri 7 Kutosari.Teknik pengumpulan data berbentuk tes, yang meliputi tes ketrampilan menulis, ketrampilan berbicara.ketrampilan membaca dan pengetahuan tentang kosakata bahasa Jawa Krama, , serta dilakukan wawancara terhadap subjek penelitian. Langkah-langkah untuk melaksanakan penelitian dengan metode deskriptif kualitatif adalah sebagai berikut (Ninoy Yudhistiya Sulistiyo, 2013: 20) : 1) menentukan populasi penelitian; 2) memilih dan menentukan sampel penelitian ; 3) mengumpulkan data; 4) pengolahan data dan analisis data; 5) Kesimpulan hasil penelitian.

Analisis data menggunakan statistik deskriptif berdasarkan rata-rata penguasaan kosakata. Pengukuran tingkat penguasaan kosakata menggunakan kriteria tabel konversi skor(Arikunto, S, 2012: 281), yaitu :

\begin{tabular}{lll}
\hline Angka & Huruf & Keterangan \\
\hline $80-100$ & A & Baik sekali \\
$66-79$ & B & Baik \\
$56-65$ & C & Cukup \\
$40-55$ & D & Kurang \\
$30-39$ & E & Gagal \\
\hline
\end{tabular}




\section{HASIL DAN PEMBAHASAN}

Hasil penelitian mengenai penguasaan kosakata bahasa Jawa Krama terhadap 15 siswa di Sekolah Dasar Negeri Pekunden dan 15 siswa di Sekolah Dasar Negeri 7 Kutosari disajikan pada table berikut:

Table hasil penelitian penguasaan kosakata bahasa Jawa Krama di Sekolah Dasar Negeri Pekunden

\begin{tabular}{lcccccc}
\hline No & Responden & Pengetahuan & $\begin{array}{c}\text { Instrument Penilaian } \\
\text { Keterampilan } \\
\text { Menulis }\end{array}$ & $\begin{array}{c}\text { Keterampilan } \\
\text { Membaca }\end{array}$ & $\begin{array}{c}\text { Keterampilan } \\
\text { Berbicara }\end{array}$ & Total \\
\hline 1. & Subjek 1 & 13 & 12 & 10 & 11 & 46 \\
2. & Subjek 2 & 13 & 11 & 9 & 5 & 38 \\
3. & Subjek 3 & 17 & 12 & 13 & 11 & 53 \\
4. & Subjek 4 & 16 & 14 & 15 & 13 & 58 \\
5. & Subjek 5 & 17 & 19 & 13 & 12 & 61 \\
6. & Subjek 6 & 13 & 10 & 10 & 11 & 44 \\
7. & Subjek 7 & 14 & 15 & 14 & 10 & 53 \\
8. & Subjek 8 & 14 & 12 & 12 & 14 & 52 \\
9. & Subjek 9 & 12 & 13 & 10 & 5 & 40 \\
10. & Subjek 10 & 22 & 13 & 10 & 9 & 54 \\
11. & Subjek 11 & 19 & 12 & 15 & 15 & 61 \\
12. & Subjek 12 & 22 & 16 & 13 & 13 & 64 \\
13. & Subjek 13 & 22 & 12 & 10 & 10 & 54 \\
14. & Subjek 14 & 10 & 8 & 10 & 7 & 35 \\
15. & Subjek 15 & 23 & 15 & 14 & 15 & 67 \\
& Rata-rata & 16,47 & 12,93 & 11,87 & 10,73 & 52 \\
\hline
\end{tabular}

Berdasarkan tabel diatas, dapat diketahui bahwa tingkat penguasaan kosakata bahasa Jawa di SD Negeri Pekunden tentang pengetahuan bahasa jawa Krama menghasilkan rata-rata kelas 16,47 , sedangkan untuk tingkat penguasaan ketrampilan menulis menghasilkan rata-rata kelas 12,93, untuk tingkat penguasaan ketrampilan membaca menghasilkan rata-rata kelas 11,87 dan untuk tingkat penguasaan berbicara menghasilkan rata-rata kelas 10,73 . Berdasarkan data tersebut tingkat penguasaan kosakata bahasa Jawa krama di SD Negeri Pekunden yaitu 52.Menurut pendapat Arikunto S (2012: 281) dengan rata-rata 52 termasuk dalam kategori kurang.

Dari data diatas diketahui bahwa di SD Negeri Pekunden masih sangat kurang dalam tingkat penguasaan kosakata bahasa Jawa, terutama pada aspek keterampilan berbicara. Pada saat proses wawancara terlihat siswa kurang mampu dalam berbicara menggunakan bahasa Jawa, penyebabnya karena siswa tidak terbiasa dalam menggunakan bahasa Jawa dalam berkomunikasi pada kehidupan sehari-hari. Hal ini sesuai dengan penelitian yang dilakukan oleh Putri (2016: 3) yang menyatakan bahwa ketrampilan berbicara bahasa Jawa krama siswa Sekolah Dasar memprihatinkan, hal ini dikarenakan siswa tidak terbiasa berkomunukasi dengan guru maupun orangtua menggunakan bahasa Jawa krama. Selain itu juga disebabkan oleh bahasa yang diajarkan oleh orang tua, yaitu mereka mengajarkan bahasa Indonesia dalam berkomunikasi pada kehidupan sehari-hari. Hal ini relevan dengan penelitian yang dilakukan oleh Nurtanti (2015: 2) yang menyatakan bahwa pihak orang tua lebih mengutamakanpengenalan bahasa Indonesia pada anak, karena orang tua juga belum menguasai bahasa Jawa secara baik, orang tua takut mengenalkan bahasa Jawa kepada anak justru akan merubah makna dari setiap kata-kata bahasa Jawa. 
Table hasil penelitian penguasaan kosakata bahasa Jawa Krama di Sekolah Dasar Negeri 7 Kutosari

\begin{tabular}{lcccccc}
\hline No & Responden & Pengetahuan & $\begin{array}{c}\text { Instrument Penilaian } \\
\text { Keterampilan } \\
\text { Menulis }\end{array}$ & $\begin{array}{c}\text { Keterampilan } \\
\text { Membaca }\end{array}$ & $\begin{array}{c}\text { Keterampilan } \\
\text { Berbicara }\end{array}$ & Total \\
\hline 1. & Subjek 1 & 12 & 7 & 5 & 3 & 27 \\
2. & Subjek 2 & 6 & 15 & 4 & 7 & 32 \\
3. & Subjek 3 & 14 & 18 & 4 & 5 & 41 \\
4. & Subjek 4 & 10 & 15 & 11 & 8 & 44 \\
5. & Subjek 5 & 3 & 5 & 5 & 3 & 16 \\
6. & Subjek 6 & 6 & 15 & 12 & 7 & 40 \\
7. & Subjek 7 & 17 & 21 & 7 & 7 & 52 \\
8. & Subjek 8 & 8 & 7 & 11 & 10 & 36 \\
9. & Subjek 9 & 4 & 16 & 7 & 7 & 34 \\
10. & Subjek 10 & 4 & 11 & 10 & 7 & 32 \\
11. & Subjek 11 & 7 & 10 & 9 & 7 & 33 \\
12. & Subjek 12 & 13 & 10 & 7 & 9 & 39 \\
13. & Subjek 13 & 9 & 5 & 6 & 10 & 30 \\
14. & Subjek 14 & 12 & 15 & 5 & 5 & 37 \\
15. & Subjek 15 & 8 & 7 & 8 & 7 & 30 \\
& Rata-rata & 8,87 & 11,8 & 7,4 & 6,8 & 34,86 \\
\hline
\end{tabular}

Berdasarkan tabel diatas, dapat diketahui bahwa tingkat penguasaan kosakata bahasa Jawa di SD Negeri 7 Kutosari tentang pengetahuan bahasa jawa Krama menghasilkan rata-rata kelas 8,87, sedangkan untuk tingkat penguasaan ketrampilan menulis menghasilkan rata-rata kelas 11,8, untuk tingkat penguasaan ketrampilan membaca menghasilkan rata-rata kelas 7,4 dan untuk tingkat penguasaan berbicara menghasilkan rata-rata kelas 6,8. Berdasarkan data tersebut tingkat penguasaan kosakata bahasa Jawa krama di SD Negeri 7 Kutosari yaitu 34,86. Menurut pendapat Arikunto S (2012: 281) dengan rata-rata 34,86 termasuk dalam kategori gagal.

Dari data diatas diketahui bahwa di SD Negeri 7 Kutosari masih sangat kurang dalam tingkat penguasaan kosakata bahasa Jawa, terutama pada aspek keterampilan berbicara..Hal ini disebabkan karena kurangnya minat belajar siswa dalam mengikuti pembelajaran bahasa Jawa, karena fungsi minat itu sendiri dapat menjadi sumber motivasi untuk belajar. Sesuai pendapat Nurtanti (2015: 2) bahwa apabila anak berminat akan sebuah kegiatan pembelajaran bahasa Jawa, maka anak akan berusaha lebih keras untuk belajar dibandingkan dengan anak yang kurang berminat. Semakin besar minat anak terhadap pembelajaran bahasa Jawa maka akan semakin baik kemampuan anak terhadap penguasaan bahasa Jawa. Selain itu, penyebab rendahnya tingkat pemahaman siswa terhadap kosakata bahasa Jawa yaitu siswa tidak terbiasa menggunakan bahasa Jawa dalam kehidupan sehari-hari. Hal tersebut dibuktikan dengan penelitian yang dilakukan oleh Rahmawati (2014: 4) bahwa lingkungan akan mempengaruhi bahasa yang digunakan anak, ketika di lingkungan tempat tinggal anak tidak terbiasa berbahasa Jawa, maka dalam mengikuti pelajaran bahasa Jawa di sekolah siswa akan kesulitan menggunakan dan memahami istilahistilah yang digunakan dalam bahasa Jawa.

\section{SIMPULAN}

Berdasarkan pembahasan dapat disimpulkan bahwa penguasaan kosakata bahasa Jawa krama di SD Negei Pekunden dan SD Negeri Kutosari memiiki hasil yang berbeda pada setiap sekolah. Pada hasil penelitian yang dilakukan dengan pengisian instrument yang meliputi 4 aspek yaitu pengetahuan, keterampilan menulis, keterampilan membaca dan keterampilan berbicara di SD Negeri Pekunden 
penguasaan kosakata bahasa Jawa dengan hasil rata-rata dari keempat aspek di atas yaitu sebesar 52, dengan hasil terendah yaitu pada aspek berbicara. Untuk SD Negeri 7 Kutosari penguasaan kosakata bahasa Jawa krama dengan hasil rata-rata dari keempat aspek yang diujikan yaitu 34,86 , dengan hasil terendah yaitu pada aspek berbicara.

\section{DAFTAR PUSTAKA}

Anwar, S. (2013). Penggunaan Bahasa Jawa Anak Usia SD di Desa Tanjungrejo Kecamatan Bayan Kabupaten Purworejo. Purworejo: Vol. 3, No. 4

Arikunto, S. (2012).Dasar-Dasar Evaluasi Pendidikan. Jakarta: Bumi Aksara

Khasanah, D. (2012). Kedudukan Bahasa Jawa Ragam Krama pada Kalangan Generasi Muda:Studi Kasus di Desa Randegan Kecamatan Dawarblandong, Mojokerto dan di Dusun Tutul Kecamatan Ambulu, Jember. Diakses pada 1 Ooktober 2018 dari https://media.neliti.com/media/publications/210165kedudukan-bahasa-jawa-ragam kramapada-ka.pdf

Nurtanti, D. (2015). Peningkatan Minat Berbahasa Jawa melalui Metode Bercerita Menggunakan Media Wayang Kartun pada Anak Kelompok TK B di TK Pedagogia Yogyakarta. Diakses pada 10 Oktober 2018 dari file://C:/Users/USER/AppData/Local/Temp/397-685-1-SM.pdf

Rahmawati, O. (2014). Pengaruh Kebiasaan Berbahasa Jawa di Rumah Terhadap Pemahaman Konsep Bahasa Jawa siswa Kelas 5 SD IT Nur Hidayah Surakarta Tahun Pelajaran 2013/2014. Diakses pada 10 Oktober 2018 dari http://eprints.ums.ac.id/27973/17/NASKAH_PUBLIKASI.pdf

Sulistiyono, Yudhistya Ninoy. (2013). Gambaran Asupan Zat Gizi Dan Aktivitas Fisik Mahasiswa IImu Keolahragaan (Study Deskriptif Pada Mahasiswa UPI Bandung).Bandung: Vol 1, No $6: 2$

Syamsuddin.,Pratiwi dan Hafidah. (2015). Peningkatan Kemampuan Kkosakata Bahasa Jawa Melalui Tembang Dolanan pada Anak Kelompok A TK Pertiwi 01 Ngringo Tahun Ajaran 2014/2015. Diakses pada 1 Oktober 2018 dari https://jurnal.fkip.uns.ac.id/index.php/paud/article/view/6764

Tondo, Fanny. (2009). Kepunahan Bahasa-Bahasa Daerah: Faktor Penyebab dan ImplikasiEtnolinguistis. Jurnal Mayarakat dan Budaya: Vol 11 No.2

Utari, Nur. (tanpa tahun). Kemampuan Berbahasa Jawa pada Siswa Sekolah Dasar di SDN Tandes Kidul I/110 Surabaya. Skriptorium, Vol. 1, No.3

Prabowo, A dan Heriyanto.(2013). Analisis Pemanfaatan Buku Elektronik (E-book) oleh Pemustaka di Perpustakaan SMA Negeri 1 Semarang.Universitas Diponegoro.Semarang. Jurnal IImu Perpustakaan: Volume 2, Nomor 2

Putri, Hilyatifa. (2016). Peningkatan Ketrampilan Berbicara Bahasa Jawa Ragam Krama Inggil melalui Model Quantum Learning pada Siswa Kelas 5 SDN Kranganyar 02 Semarang. Diakses pada 10Oktober 2018 dari http://lib.unnes.ac.id/27000/1/1401410165.pdf

Waluyo, A. (2010). Pembelajaran Bahasa Jawa Ragam Krama pada Masyarakat Samin diDukuh Tambak Desa Sumber Kecamatan Kradenan Kabupaten Blora. Diakses pada 1 Oktober 2018 dari http://lib.unnes.ac.id/3764/1/8220.pdf

Wulandari, D. (2012). Penggunaan Tingkat Tutur Bahasa Jawa Siswa Kelas 1 SD Negeri 2 Trenten Kecamatan Candimulyo Magelang. Diakses pada 5 Oktober 2018

dari file://C:/Users/USER/Downloads/SEMINAR/Dwi\%2520Wulandari 0720524404 8.pdf 